\title{
NLR, MPV and RDW as Biomarkers in Operated and Non-operated Patients with Colorectal Adenocarcinoma
}

\author{
Opere ve Non-opere Kolorektal Adenokarsinoma Hastalarında \\ Biyobelirteç Olarak NLR, MPV ve RDW
}

\author{
(D) Atilla Bulurr1, (D) Ayça Serap Çakır²
}

${ }^{1}$ Nazilli State Hospital, Clinic of Gastroenterology, Aydın, Turkey

${ }^{2}$ Medicana Çamlıca Hospital, Clinic of Internal Medicine, İstanbul, Turkey

\section{Abstract}

Objective: There is a need for inexpensive, reliable and readily available biomarkers in the early diagnosis and prediction of mortality, morbidity and treatment response in colorectal cancer (CRC). In our study, it was aimed to compare mean platelet volume (MPV), red cell distribution width (RDW) and neutrophil-lymphocyte ratio (NLR) measurements in operated and non-operated patients with the diagnosis of CRC.

Method: In our study, we retrospectively reviewed 52 patients (including 26 operated patients and 26 non-operated patients) diagnosed as CRC with colonoscopic biopsy at endoscopy unit of gastroenterology department between 2016 and 2019. We extracted and compared demographic, colonoscopy, clinical, laboratory and surgical data in both groups.

Results: In our study, the mean age (60.04 years and 64.19 years, respectively) and gender distribution (female: male, 12/16 and 10/14, respectively) were comparable in operated and non-operated patients with CRC. MPV, RDW and NLR measurements were found to be significantly lower in patients who underwent surgery (operated) when compared to non-operated patients $(p<0.001, p=0.026$ and $p<0.001$, respectively).

Conclusion: There is strong evidence suggesting that inflammation plays a role in the pathogenesis of many disorders including malignancy. In our study, it was found that inflammatory markers, namely MPV, RDW and NLR values, were lower after surgery which removed tumor; thus, inflammation. These biomarkers can be suggestive for early diagnosis in $\mathrm{CRC}$ as well as response to surgical treatment.

Keywords: NLR (neutrophil-lymphocyte ratio), MPV (mean platelet volume), RDW (red cell distribution width), operation, colorectal adenocarcinoma

\section{Öz}

Amaç: Kolorektal kanserin (KRK) erken tanısında, mortalite, morbidite ve tedavi yanıtının tahmin edilmesinde kolayca ulaşılabilir, ucuz ve güvenilir biyobelirteçlere intiyaç vardır. Çalışmamızda KRK tanısı ile opere olan ve opere olmayan hastaların ortalama trombosit hacmi (MPV), eritrosit dağılım genişliği (RDW) ve nötrofil-lenfosit oranı (NLR) ölçümlerini karşılaştırmak amaçlanmıştır.

Yöntem: Çalışmamızda 2016-2019 yılları arasında hastanemiz gastroenteroloji kliniği, endoskopi ünitemizde kolonoskopik biyopsi ile KRK tanısı alan ve 26'sı opere, 26'sı non-opere toplam 52 hasta incelenmiştir. Her iki hasta grubuna ait demografik, kolonoskopik, klinik, laboratuvar ve operasyonel bilgiler restrosepektif olarak irdelenmiş ve karşılaştırılmıştır

Bulgular: Çalışmamızda opere ve non-opere KRK hastaların yaş ortalamaları (60,04 ve 64,19 yaş) ve cinsiyet (kadın/erkek: 12/16 ve 10/14) özellikleri birbirine benzerdi. Opere olarak cerrahi tedavi uygulanan hastaların, cerrahi tedavi olmayan non-opere hastalara göre MPV, RDW ve NLR ölçümleri istatistiksel olarak anlamlı ölçüde düşük saptandı $(p<0,001, p=0,026, p<0,001)$.

Sonuç: Kronik enflamasyonun, malignite dahil birçok hastalığın patogenezinde rol oynadığına dair güçlü kanıtlar mevcuttur. Çalışmamızda araştırdığımız enflamatuvar göstergeler olan MPV, RDW ve NLR düzeylerinin, tümörün ve dolayısıyla enflamasyonun ortadan kalkmasına neden olan operasyon sonrası düşük düzeylerde olduğu saptanmıştır. Bu biyobelirteçler KRK erken tanısı için fikir verebileceği gibi, cerrahi tedavi yanıtı hakkında da bilgi verebilir.

Anahtar kelimeler: NLR (nötrofil-lenfosit oranı), MPV (ortalama trombosit hacmi), RDW (eritrosit dağılım genişliği), operasyon, kolorektal adeno karsinom

Address for Correspondence: Atilla Bulur, Nazilli State Hospital, Clinic of Gastroenterology, Aydın, Turkey E-mail: atillabulur@hotmail.com ORCID: orcid.org/ 0000-0001-8089-7740 Received: 03.05.2021 Accepted: 15.08.2021

Cite this article as: Bulur A, Çakır AS. NLR, MPV and RDW as Biomarkers in Operated and Non-operated Patients with Colorectal Adenocarcinoma. Bagcilar Med Bull 2021;6(3):314-319

@ Copyright 2021 by the Health Sciences University Turkey, Bagcilar Training and Research Hospital Bagcilar Medical Bulletin published by Galenos Publishing House. 


\section{Introduction}

Colorectal cancer (CRC) is the third most common cancer whereas fourth most common cause of cancer-related mortality worldwide (1). As similar to many other cancers, the likelihood of successful treatment is increased if diagnosed early (2). Although colonoscopy remains to be the most effective modality in detecting CRC, inconvenient experience, risk of complication and higher costs limit its use in screening settings $(3,4)$. In CRC, fecal occult blood test and fecal immunochemical test are most commonly used biomarkers in CRC screening. However, the sensitivity of these tests is variable as they are affected from diet and unable to distinguish between upper and lower gastrointestinal bleeding $(5,6)$. Despite apparent improvements in the diagnosis and treatment of CRC in recent years, the diagnosis is still made at advanced stages in majority of patients, resulting in poor prognosis. Thus, there is a need for biomarkers that improve survival and inform early diagnosis, treatment response and prognosis. There are clinical studies investigating non-invasive, readily available and inexpensive tumor biomarkers with high accuracy. These are mostly molecules that show elevated levels with inflammation and immune reactions. Chronic inflammation has been linked with many immune reactions, a number of disease and poor outcomes. In recent studies, growing evidence shows that inflammation and immune response play pivotal role in the development and progression of several cancers including CRC (7-9). It has been reported that inflammation can lead to CRC development through increased production of leukocytederived cytokines and reactive oxygen species resulting in DNA damage and subsequent dysplasia. In addition, inflammation may lead tumoral cell proliferation and promote angiogenesis (10). Systemic inflammation markers such as C-reactive protein, neutrophil-lymphocyte ratio (NLR), mean platelet volume (MPV) and red cell distribution width (RDW) were investigated in several studies and it was reported that the levels of these molecules were elevated in some cancers including CRC and that they were associated with poor differentiation, poor prognosis and mortality (11-17). These biomarkers can be analyzed in almost all healthcare facilities, which can be measured from peripheral blood samples using complete blood count (CBC) test. Neutrophils represent a large subclass of leukocytes. In carcinogenesis process, there was an increase in NLR due to increased neutrophil count and decreased lymphocyte count in peripheral blood (18). MPV, a marker for platelet size and activity, is accepted as an inflammatory marker in cardiovascular, cerebrovascular, rheumatoid and gastroenterological disorders. In addition, there are studies supporting that MPV can be a marker for early diagnosis in gastric, pancreatic, hepatocellular cancer and CRC $(13,18,19)$. RDW is a parameter that represents size heterogeneity of red blood cells, which is used to discriminate several anemia types. In recent studies, it has been reported that RDW is a biochemical marker associated with many chronic inflammatory and cardiovascular disease and that it may be used as a prognostic marker in several cancers such as lung cancer, esophagus cancer, gastric cancer, hepatocellular carcinoma and breast cancer (20-22). Thus, it is reasonable to anticipate that treatment or surgical removal of tumor would cause decrease in these biomarkers. In a few studies, it was reported that NLR, platelet: lymphocyte ratio (PLR) and MPV values were regressed following surgical tumor resection in CRC when compared to preoperative values $(13,19)$. The aim of this study was to elucidate effectiveness and capability of MPV, NLR and RDW as non-invasive diagnostic biomarkers in $\mathrm{CRC}$ and to investigate reduction anticipated in the markers following surgical treatment.

\section{Materials and Methods}

In this study, we retrospectively reviewed demographic, colonoscopic, clinical, laboratory data and histopathological features in 52 patients (aged $>18$ years) who were diagnosed as colorectal adenocarcinoma by colonoscopic biopsy performed for any reason in our endoscopy unit of gastroenterology department between 2016 and 2019. Of these patients, 26 were diagnosed as CRC in our endoscopy unit but not received any treatment (non-operated patients) while 26 patients were diagnosed as CRC in our endoscopy unit and followed in our outpatient clinic after surgery performed in different hospitals (operated patients). In our study, primary objective was to compare MPV, NLR and RDW values extracted from CBC studied in our laboratory between operated and non-operated ones. Blood samples $(2 \mathrm{~mL})$ were drawn from cubital vein following 8-hour fasting. Blood samples coagulated using EDTA were analyzed by hematology analyzer within 2-4 hours. The MPV and RDW results were directly extracted from CBC report while NLR was calculated by dividing absolute neutrophil count with absolute lymphocyte count. The normal values were $6-10 \mathrm{fL}$ for MPV and $12-16 \%$ for RDW. The colonoscopy (Fujinon, ED550 colonoscopy device, Japan) was performed following 24-hour colon preparation and 8-hour fasting under sedation-analgesia supervised by an anesthesiologist. Multiple biopsies were taken from lesions seen during colonoscopy. The biopsy specimens 
were placed in $10 \%$ formalin and sent to histopathology laboratory. There were comorbid diabetes mellitus, hypertension and chronic ischemic heart diseases. The patients with a history of secondary malignancy, patients with metastatic CRC, patients with fatal outcome at any time, those received blood product transfusion within prior 6 months and patients who underwent chemotherapy and radiotherapy were excluded. The study was approved by Institutional Ethics Committee.

\section{Statistical Analysis}

Continuous variables were presented as descriptive statistics (mean, standard deviation, minimum, median, maximum). Categorical variables were presented in frequency and percentage. The Mann-Whitney U test was used to compare two independent, continuous variables with skewed distribution. The Spearman's rho correlation test was used to assess the relationship between two continuous variables with skewed distribution. Statistical significance level was set as 0.05 . All statistical analyses were performed using the MedCalc Statistical Software version 12.7.7 (MedCalc Software bvba, Ostend, Belgium; http://www.medcalc.org; 2013).

\section{Results}

The study included 52 patients. The mean age was $62.12 \pm 12.5$ years. There were 30 men and 22 women. Of 52 patients, 26 (50\%) were non-operated CRC patients while $26(50 \%)$ were operated CRC patients. The mean age was 60.04 years (35-71) in the operated group whereas 64.19 years (44-88) in the non-operated group. There were 12 women and 16 men in the operated group whereas 10 women and 14 men in the non-operated group. Sigmoid colon $(n=19,36.5 \%)$ and rectum $(\mathrm{n}=12,23.1 \%)$ were found as the most common CRC localization cited in colonoscopy reports (Table 1). Table 2 summarizes the mean hemoglobin, MPC, RDW and NLR values of all patients included. Table 3 and Figure 1 summarize the comparison of mean MPV, RDW and NLR measurements between the operated and non-operated groups. The mean MPV, RDW and NLR measurements were found to be significantly lower in operated patients when compared to non-operated patients $(\mathrm{p}<0.001, \mathrm{p}=0.026$ and $\mathrm{p}<0.001$, respectively). A significant correlation was detected in hemoglobin measurements of groups ( $\mathrm{p}=0.010$ ) and hemoglobin value was found to be higher in the operated group (Table 3, Figure 1).
Table 1. Demographics and tumor locations

\begin{tabular}{llll} 
& & Mean \pm SD & Med (min-max) \\
\hline Age (year) & & $62.12+12.5$ & $64(35-88)$ \\
Operation & N & $\%$ \\
& Operated & 26 & 50.0 \\
\cline { 2 - 2 } Gender & Non-operated & 26 & 50.0 \\
& Male & 30 & 57.7 \\
& Female & 22 & 42.3 \\
& Rectum & 12 & 23.1 \\
& Sigmoid colon & 19 & 36.5 \\
& Descending colon & 6 & 11.5 \\
& Transverse colon & 7 & 13.5 \\
& Ascending colon & 5 & 9.6 \\
& Cecum & 3 & 5.8
\end{tabular}

SD: Standard deviation

Table 2. The average of Hb, MPV, RDW, NLR

\begin{tabular}{lll} 
& Mean \pm SD & Med (min-max) \\
\hline Hb (gr/dL) & $12.1+1.6$ & $12.3(8.9-14.8)$ \\
MPV (fL) & $9.09+1.64$ & $9.2(5.7-12.3)$ \\
RDW (\%) & $15.4+3.83$ & $14.5(8.7-27.2)$ \\
NLR & $2.42+0.94$ & $2.39(0.68-4.57)$
\end{tabular}

SD: Standard deviation, $\mathrm{Hb}$ : Hemoglobin, MPV: Mean platelet volume, RDW: Red cell distribution width, NLR: Neutrophil-lymphocyte ratio

\section{Discussion}

The role of chronic inflammation has been extensively investigated in the carcinogenesis. In a study by Itzkowitz and Yio (9), it was reported that chronic inflammation led to CRC development without classical adenoma-carcinoma sequence in patients with inflammatory bowel disease (IBD). In addition, in a study supporting this assumption, Burr et al. (23) showed that non-steroidal anti-inflammatory drugs decreased CRC risk by decreasing systemic inflammation in IBD patients. Systemic inflammation is very important in early cancer development (24). Neutrophils provoke proliferation of tumor cells, angiogenesis and metastasis by activating production of growth factors such as vascular endothelial growth factor and PK2/Bv8 and cytokines such as IL-1, IL-6 and tumor necrosis factor $(25,26)$.

NLR has been proposed as a good marker for systemic, low-grade inflammation which is associated with poorer prognosis in many diseases $(27,28)$. In a meta-analysis on prognostic effect of NLR in several solid tumors, elevated NLR was linked to mortality in many cancer types at difference stages. In a milestone study by Walsh et al. (29), NLR $>5$ was found to be associated with decreased overall and cancer-specific survival. In another study, it was 
Table 3. The comparison of operated and non-operated $\mathrm{Hb}$, MPV, RDW, NLR

\begin{tabular}{llll} 
& Operated & Nonoperated & \\
\hline & $\begin{array}{l}\text { Mean } \pm \text { SD } \\
\text { Med (min-max) }\end{array}$ & $\begin{array}{l}\text { Mean } \pm \text { SD } \\
\text { Med (min-max) }\end{array}$ & p* \\
& $12.66 \pm 1.23$ & $11.49 \pm 1.68$ & 0.010 \\
$\mathbf{H b}$ & $12.65(10.5-14.8)$ & $11.1(8.9-14.5)$ & \\
$\mathbf{( g r / d L )}$ & $8.2 \pm 1.46$ & $9.98 \pm 1.3$ & $<0.001$ \\
$\mathbf{M P V}$ & $8.1(5.7-11)$ & $10.15(7.4-12.3)$ & \\
$\mathbf{( f L )}$ & $14.48 \pm 3.68$ & $16.32 \pm 3.83$ & 0.026 \\
$\mathbf{R D W}$ & $13.8(10-27.2)$ & $15.45(8.7-23)$ & \\
$\mathbf{( \% )}$ & $1.91 \pm 0.7$ & $2.93 \pm 0.88$ & $<0.001$ \\
$\mathbf{N L R}$ & $1.88(0.68-3.49)$ & $2.9(1.27-4.57)$ & \\
\hline
\end{tabular}

*Mann-Whitney U test, SD: Standard deviation, Hb: Hemoglobin, MPV: Mean platelet volume, RDW: Red cell distribution width, NLR: Neutrophil-lymphocyte ratio

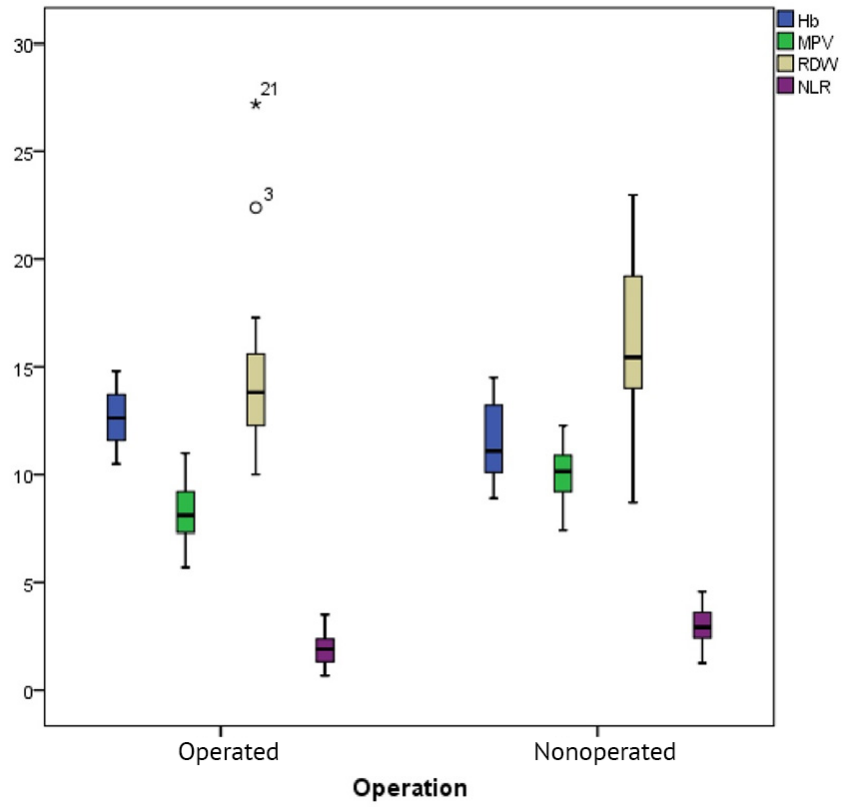

Figure 1. The measurements of Hb, MPV, RDW, NLR according to operation

Hb: Hemoglobin, MPV: Mean platelet volume, RDW: Red cell distribution width, NLR: Neutrophil-lymphocyte ratio

found that lower postoperative NLR was correlated with longer cancer-specific and disease-free survival in patients who underwent elective CRC resection (30). Again, it was reported that disease-free survival was decreased while cancer-mortality was increased in CRC patients with high preoperative NLR (>3) (31). In a study on patients with early stage CRC, who were candidates for curative surgery, it was found that 5-year disease-free survival and cancerspecific survival were significantly poorer in patients with high NLR values (32). In some studies, it was reported that there was an increase in perioperative complications including postoperative wound site infection, anastomosis dehiscence, morbidity and mortality in CRC patients with high NLR values $(30,33,34)$. In our study, the mean NLR value was $1.91 \pm 0.7$ in the operated group and $2.93 \pm 0.88$ in the non-operated group; the mean NLR value was significantly lower in the operated group $(\mathrm{p}<0.001$, Table 3 , Figure 1).

In a study on 153 patients with resectable CRC, it was reported that patients with lower preoperative MPV values had more advanced disease, that MPV was increased by adjuvant chemotherapy while it was significantly decreased after surgery, and that preoperative MPV value $<1$ was associated with poorer survival (35). In CRC, it was reported that higher MPV level was associated with the presence of cancer, shorter overall survival and negative effect on progression-free survival (14,36-38). In our study, the mean MPV value was $8.2 \pm 1.46 \mathrm{fL}$ in operated patients and $9.98 \pm 1.3 \mathrm{fL}$ in non-operated patients. The mean MPV value was found to be significantly lower in operated patients $(\mathrm{p}<0.001$, Table 3, Figure 1).

In many studies, RDW has been investigated as a potential prognostic marker for CRC. However, given the inconsistent results regarding malignancy, the role of RDW remains to be unclear in cancer. In a study, high $\mathrm{RDW}$ values were found to be associated with lower 10-year survival when compared to CRC patients with lower RDW values; however, no significant difference was observed in 5-year survival (39). In our study, the mean RDW was $14.48 \pm 3.68$ in the operated group and $16.32 \pm 3.83$ in the non-operated group. The mean RDW was significantly lower in the operated group ( $\mathrm{p}<0.026$, Table 3 , Figure 1$)$. In a study from Turkey, Kilincalp et al. (19) showed that NLR, PLR and MPV levels were significantly lower in patients with CRC when compared to controls and that there were significant reductions in NLR, PLR and MPV after surgical tumor resection. As similar to our study, authors suggested that this triple biomarker set could have clinical value in early diagnosis, screening and postoperative follow-up in CRC (19). In the literature, there are studies evaluating several biomarkers in CRC patients; however, to best of our knowledge, there is no study investigating these three biomarkers set together. In addition, in our study, the mean hemoglobin level was found to be significantly lower in operated patients when compared to non-operated patients $(12.66 \pm 1.23 \mathrm{~g} / \mathrm{dL}$ and $11.49 \pm 1.68 \mathrm{~g} / \mathrm{dL}$, Table 1$)$. This may be linked with the treatment of tumor, which is a cause of anemia, but it may also be explained by iron 
therapy and erythrocyte suspensions given before and after surgery.

\section{Study Limitations}

This study has some limitations including its retrospective design, relatively small sample size and surgery. Moreover, the fact that surgical treatment and postoperative care were performed in other facilities is another limitation. In the future, multi-center, prospective studies with larger sample size, which will involve preoperative and postoperative follow-up periods, could be designed.

\section{Conclusion}

In the literature, there are many biomarkers linked with inflammation and several malignancies, including NLR, MPV and RDW. In our study, NLR, MPV and RDW values were found to be significantly lower in patients who underwent surgical treatment when compared to nonoperated patients. In conclusion, we believe that this triple biomarker set can provide important data for early diagnosis, screening and response to surgical treatment in CRC patients.

\section{Ethics}

Ethics Committee Approval: The study was approved by Zeynep Kamil Maternity and Children's Training and Research Hospital, Institutional Ethics Committee.

Informed Consent: Patient consent was obtained.

Peer-review: Externally peer-reviewed.

\section{Authorship Contributions}

Concept: A.B., A.S.Ç., Design: A.B., A.S.Ç., Data Collection or Processing: A.B., A.S.Ç., Analysis or Interpretation: A.B., Literature Search: A.B., Writing: A.B., Manuscript Review and Revisation: A.B., A.S.Ç.

Conflict of Interest: No conflict of interest was declared by the authors.

Financial Disclosure: The authors declared that this study received no financial support.

\section{References}

1. Bhattacharjee D, Quirke P. What is the Role of the Neutrophil: Lymphocyte Ratio in Colorectal Cancer? Turk J Colorectal Dis 2021;31(1):1-12

2. Levin TR, Jamieson L, Burley DA, Reyes J, Oehrli M, Caldwell C. Organized Colorectal Cancer Screening in Integrated Health Care Systems. Epidemiol Rev 2011;33(1):101-110.

3. Peng HX, Yang L, He BS, Pan YQ, Ying HQ, Sun HL, et al. Combination of preoperative NLR, PLR and CEA could increase the diagnostic efficacy for I-III stage CRC. J Clin Lab Anal 2017;31(5):e22075. doi: $10.1002 /$ jcla. 22075

4. Ribeiro MS, Wallace MB. Endoscopic treatment of early cancer of the colon. Gastroenterol Hepatol (N Y) 2015;11(7):445-452.

5. Song LL, Li YM. Current noninvasive tests for colorectal cancer screening: An overview of colorectal cancer screening tests. World J Gastrointest Oncol 2016;8(11):793-800.

6. Sanford KW, McPherson RA. Fecal occult blood testing. Clin Lab Med 2009;29:523-541.

7. Colotta F, Allavena P, Sica A, Garlanda C, Mantovani A. Cancerrelated inflammation, the seventh hallmark of cancer: links to genetic instability. Carcinogenesis 2009;30(7):1073-1081.

8. ElinavE, NowarskiR, Thaiss CA, Hu B, Jin C, Flavell RA. Inflammation induced cancer: crosstalk between tumours, immune cells and microorganisms. Nat Rev Cancer 2013;13(11):759-771.

9. Itzkowitz SH, Yio X. Inflammation and cancer IV. Colorectal cancer in inflammatory bowel disease: the role of inflammation. Am J Physiol Gastrointest Liver Physiol 2004;287(1):G7-17. doi: 10.1152/ ajpgi.00079.2004

10. Mantovani A, Allavena P, Sica A, Balkwill F. Cancer related inflammation. Nature 2008;454(7203):436-444.

11. Azab B, Shah N, Radbel J, Tan P, Bhatt V, Vonfrolio S, et al Pretreatment neutrophil/lymphocyte ratio is superior to platelet/ lymphocyte ratio as a predictor of long-term mortality in breast cancer patients. Med Oncol 2013;30(1):432.

12. Liu H, Wu Y, Wang Z, Yao Y, Chen F, Zhang H, et al. Pretreatment platelet-to-lymphocyte ratio (PLR) as a predictor of response to first-line platinum-based chemotherapy and prognosis for patients with non-small cell lung cancer. J Thorac Dis 2013;5(6):783-789.

13. Li JY, Li Y, Jiang Z, Wang RT, Wang XS. Elevated mean platelet volume is associated with presence of colon cancer. Asian Pac J Cancer Prev 2014;15(23):10501-10504.

14. Li N, Yu Z, Zhang X, Liu T, Sun YX, Wang RT, et al. Elevated mean platelet volume predicts poor prognosis in colorectal cancer. Sci Rep 2017;7(1):10261.

15. Lippi G, Targher G, Montagnana M, Salvagno GL, Zoppini G, Guidi GC. Relation between red blood cell distribution width and inflammatory biomarkers in a large cohort of unselected outpatients. Arch Pathol Lab Med 2009;133(4):628-632.

16. Perlstein TS, Weuve J, Pfeffer MA, Beckman JA. Red blood cell distribution width and mortality risk in a community-based prospective cohort. Arch Intern Med 2009;169(6):588-594.

17. Cengiz M, Sahin A, Özdil K, Sökmen HM. Role of RDW and MPV in Diagnosis of Colorectal Polyps and Carcinoma: A Case-Control Study. Acta Oncologica Turcica · 2015. doi: 10.5505/aot.2015.96268

18. Lalosevic MS, Markovic AP, Stankovic S, Stojkovic M, Dimitrijevic I, Vujavic IR, et al. Combined diagnostic efficacy of neutrophilto-lymphocyte ratio (NLR), platelet-to-lymphocyte ratio (PLR), and mean platelet volume (MPV) as biomarkers of systemic inflammation in the diagnosis of colorectal cancer. Dis Markers 2019;2019:6036979. doi: 10.1155/2019/6036979.

19. Kilincalp S, Coban S, Akinci H, Hamamcı M, Karaahmet F, Coşkun Y, et al. Neutrophil/lymphocyte ratio, platelet/lymphocyte ratio, and mean platelet volume as potential biomarkers for early detection and monitoring of colorectal adenocarcinoma. Eur J Cancer Prev 2015;24(4):328-333.

20. Hu Z, Sun Y, Wang Q, Han Z, Huang Y, Liu X, et al. Red blood cell distribution width is a potential prognostic index for liver disease. Clin Chem Lab Med 2013;51(7):1403-1408. 
21. Li N, Zhou H, Tang Q. Red blood cell distribution width: a novel predictive indicator for cardiovascular and cerebrovascular diseases. Dis Markers 2017;2017:7089493. doi: $10.1155 / 2017 / 7089493$.

22. Hu L, Li M, Ding Y, Pu L, Liu J, Xie J, Cabanero M, et al. Prognostic value of RDW in cancers: a systematic review and meta-analysis. Oncotarget 2017;8(9):16027-16035.

23. Burr NE, Hull MA, Subramanian V. Does aspirin or non-aspirin non-steroidal anti-inflammatory drug use prevent colorectal cancer in inflammatory bowel disease? World J Gastroenterol 2016;22(13):3679-3686.

24. Mariani F, Sena P, Roncucci L. Inflammatory pathways in the early steps of colorectal cancer development. World J Gastroenterol 2014;20(29):9716-9731.

25. Tecchio C, Cassatella MA. Neutrophil-derived cytokines involved in physiological and pathological angiogenesis. Chem Immunol Allergy 2014;99:123-137.

26. Wang Z, Jin H, Xu R, Mei Q, Fan D. Triptolide downregulates Rac1 and the JAK/STAT3 pathway and inhibits colitis-related colon cancer progression. Exp Mol Med 2009;41(10):717-727.

27. Wan H, Wang Y, Fang S, Chen Y, Zhang W, Xia F, et al. Associations between the neutrophil-to-lymphocyte ratio and diabetic complications in adults with diabetes: a cross-sectional study. J Diabetes Res 2020;2020:6219545. doi: 10.1155/2020/6219545.

28. Hung HY, Chen JS, Yeh CY, Changchien CR, Tang R, Hsieh PS et al. Effect of preoperative neutrophil-lymphocyte ratio on the surgical outcomes of stage II colon cancer patients who do not receive adjuvant chemotherapy. Int J Colorectal Dis 2011;26(8):1059-1065.

29. Walsh SR, Cook EJ, Goulder F, Justin TA, Keeling NJ. Neutrophillymphocyte ratio as a prognostic factor in colorectal cancer. J Surg Oncol 2005;91(3):181-184.

30. Kubo T, Ono S, Ueno H, Shinto E, Yamamoto J, Hase K. Impact of the perioperative neutrophil-to-lymphocyte ratio on the long-term survival following an elective resection of colorectal carcinoma. International J Colorectal Dis 2014;29(9):1091-1099.
31. Chiang SF, Hung HY, Tang R, Changchien CR, Chen JS, You YT, et al. Can neutrophil-to-lymphocyte ratio predict the survival of colorectal cancer patients who have received curative surgery electively? Int J Colorectal Dis 2012;27(10):1347-1357.

32. Shin JS, Suh KW, Oh SY. Preoperative neutrophil to lymphocyte ratio predicts survival in patients with T1-2N0 colorectal cancer. J Surg Oncol 2015;112(6):654-657.

33. Haram A, Boland MR, Kelly ME, Bolger JC, Waldron RM, Kerin MJ. The prognostic value of neutrophil-to-lymphocyte ratio in colorectal cancer: A systematic review. J Surg Oncol 2017;115(4):470-479.

34. Josse JM, Cleghorn MC, Ramji KM, Jiang H, Elnahas A, Jackson TD et al. The neutrophil-to-lymphocyte ratio predicts major perioperative complications in patients undergoing colorectal surgery. Colorectal Dis 2016;18:O236-O242. doi: 10.1111/ codi.13373.

35. Qian W, Ge XX, Wu J, Gong FR, Wu MY, Xu MD, et al. Prognostic evaluation of resectable colorectal cancer using platelet-associated indicators. Oncol Lett 2019;18(1):571-580.

36. Pyo JS, Sohn JH, Kang G. Diagnostic and prognostic roles of the mean platelet volume in malignant tumors: a systematic review and meta-analysis. Platelets 2016;27(8):722-728.

37. Tuncel T, Ozgun A, Emirzeoglu L, Celik S, Bilgi O, Karagoz B. Mean platelet volume as a prognostic marker in metastatic colorectal cancer patients treated with bevacizumab-combined chemotherapy. Asian Pac J Cancer Prev 2014;15(15):6421-6423.

38. Wodarczyk M, Kasprzyk J, Sobolewska-Wodarczyk A, Wodarczyk J, Tchorzewski M, Dziki A, et al. Mean platelet volume as a possible biomarker of tumor progression in rectal cancer. Cancer Biomark 2016;17(4):411-417.

39. Pedrazzani C, Tripepi M, Turri G, Fernandes E, Scotton G, Conci S,et al. Prognostic value of red cell distribution width (RDW) in colorectal cancer. Results from a single-center cohort on 591 patients. Sci Rep 2020;10(1):1072. 